\title{
The aluminum distribution and translocation in two citrus species differing in aluminum tolerance
}

\author{
Han Zhang ${ }^{1,2}$, Xin-yu Li ${ }^{1}$, Mei-lan Lin ${ }^{1}$, Ping-ping Hu ${ }^{1}$, Ning-wei Lai ${ }^{1}$, Zeng-rong Huang ${ }^{1 *}$ (D) and Li-song Chen ${ }^{1}$
}

\begin{abstract}
Background: Many citrus orchards of south China suffer from soil acidification, which induces aluminum (Al) toxicity. The Al-immobilization in vivo is crucial for Al detoxification. However, the distribution and translocation of excess Al in citrus species are not well understood.

Results: The seedlings of 'Xuegan' [Citrus sinensis (L.) Osbeck] and 'Shatianyou' [Citrus grandis (L.) Osbeck], that differ in Al tolerance, were hydroponically treated with a nutrient solution (Control) or supplemented by $1.0 \mathrm{mM} \mathrm{Al}{ }^{3+}(\mathrm{Al}$ toxicity) for 21 days after three months of pre-culture. The Al distribution at the tissue level of citrus species followed the order: lateral roots $>$ primary roots $>$ leaves $>$ stems. The concentration of Al extracted from the cell wall (CW) of lateral roots was found to be about 8 to 10 times higher than in the lateral roots under Al toxicity, suggesting that the CW was the primary Al-binding site at the subcellular level. Furthermore, the Al distribution in CW components of the lateral roots showed that pectin had the highest affinity for binding Al. The relative expression level of genes directly relevant to Al transport indicated a dominant role of Cs6g03670.1 and Cg1g021320.1 in the Al distribution of two citrus species. Compared to C. grandis, C. sinensis had a significantly higher Al concentration on the CW of lateral roots, whereas remarkably lower Al levels in the leaves and stems. Furthermore, Al translocation revealed by the absorption kinetics of the CW demonstrated that C. sinensis had a higher Al retention and stronger Al affinity on the root CW than C. grandis. According to the FTIR (Fourier transform infrared spectroscopy) analysis, the Al distribution and translocation might be affected by a modification in the structure and components of the citrus lateral root CW.

Conclusions: A higher Al-retention, mainly attributable to pectin of the root CW, and a lower Al translocation efficiency from roots to shoots contributed to a higher Al tolerance of $C$. sinensis than C. grandis. The aluminum distribution and translocation of two citrus species differing in aluminum tolerance were associated with the transcriptional regulation of genes related to $\mathrm{Al}$ transport and the structural modification of root $\mathrm{CW}$.
\end{abstract}

Keywords: Citrus sinensis, Citrus grandis, Al toxicity, Al distribution, Al translocation, Cell wall

\section{Background}

Acidification of arable soils has increased in China from 1980 to $2000 \mathrm{~s}$ [1]. Soil acidification significantly accelerates aluminum $(\mathrm{Al})$ solubilization from minerals when

\footnotetext{
*Correspondence: hzrapaul@126.com

${ }^{1}$ College of Resources and Environment, Fujian Agriculture and Forestry University, 350002 Fuzhou, China

Full list of author information is available at the end of the article
}

the soil $\mathrm{pH}$ is less than 5.0 [2]. The excess $\mathrm{Al}$ in the soil disturbs the nutrient and water balance of the rhizosphere, thereby reducing crop yield [3], and represents one of the most limiting factors to crop production in tropical and subtropical regions [4]. For instance, it was reported that rice grain yield decreased by $28-62 \%$ [5], and wheat grain yield decreased by $23-100 \%$ [6] under Al toxicity.

The citrus orchards in south China frequently suffer from Al toxicity induced by soil acidification [7]. For 
instance, our investigation of 319 soil samples from citrus orchards in Fujian province of China revealed an average $\mathrm{pH}$ of 4.34 , over $90 \%$ of which had a pH less than 5.0 [8]. Under field conditions, excess Al significantly inhibited the root development of Citrus aurantium L. [9]. Accordingly, the citrus fruit yield also decreased significantly under $\mathrm{Al}$ toxicity [10]. In sandy culture, the biomass of citrus seedlings was depressed by $\mathrm{Al}$ toxicity, inducing the oxidative stress and the photosynthetic inhibition of citrus seedlings [11]. Likewise, in the hydroponic culture, high $\mathrm{Al}$ concentration induces chlorotic and mottled leaves, thick root tips and less fibrous roots of citrus rootstocks [12].

Plant tolerance to excess $\mathrm{Al}$ mainly relies on the inhibition of $\mathrm{Al}$ uptake and the restriction of $\mathrm{Al}$ translocation [13]. Excess $\mathrm{Al}$ accumulates primarily in the roots of citrus seedlings $[14,15]$. Furthermore, $\mathrm{Al}$ partitioning at the cellular level shows that the plant root $\mathrm{CW}$ is the primary location for Al-binding for most crops [16]. The CW was constituted mainly by polysaccharides, such as pectin, cellulose and hemicellulose (HC). However, it is still debatable which $\mathrm{CW}$ component contributes most to the Al-binding under high $\mathrm{Al}$ concentrations. For instance, Yang et al. [17] reported that $\mathrm{HC}$ is the main pool for $\mathrm{Al}$ accumulation in Arabidopsis. Differentially, Ye et al. [18] proposed that the $\mathrm{CW}$ pectin contributed mainly to $\mathrm{Al}$ binding in Panax notoginseng, a native plant adapted to acid soil. To our knowledge, the Al distribution pattern and the primary $\mathrm{Al}$ repository sites in citrus species are still less clear. Moreover, the potential mechanisms regarding the $\mathrm{Al}$ distribution and translocation in citrus species are not fully understood and documented.

Genes associated with $\mathrm{Al}$ transport and redistribution have been explored. For instance, the gene encoding $\mathrm{Al}$ Sensitive 3 (ALS3) has been identified in Arabidopsis and is responsible for $\mathrm{Al}$ transport from roots to shoots [19]. Moreover, the upregulation of $\mathrm{Al}$-specific transporter Nramp (natural resistance-associated macrophage protein) has been proven to enhance rice $\mathrm{Al}$ sensitivity [20]. Our transcriptional study on $\mathrm{Al}$-treated citrus roots also indicated the roles of Cs3g18690.1 and Cs6g05460.1 in Al transport and detoxification [21].

We have evaluated the $\mathrm{Al}$ tolerance of 12 citrus species and cultivars in 2009 at an $\mathrm{AlCl}_{3} \cdot 6 \mathrm{H}_{2} \mathrm{O}$ concentration of $0,0.2,0.6,1.0$ and $1.6 \mathrm{mM}$ [22]. The results indicated C. sinensis is Al-tolerant and C. grandis is an $\mathrm{Al}$-sensitive species. Further studies were carried out to investigate the different responses of $C$. sinensis and $C$. grandis to $\mathrm{Al}$ stress at bio-physiological $[11,23]$, transcriptional $[19,24]$ and proteomic levels $[25,26]$. However, potential $\mathrm{Al}$-tolerant mechanisms in relation to $\mathrm{Al}$ distribution and translocation of citrus species are less well understood. In the present study, seedlings of
C. sinensis (Al-tolerant) and C. grandis (Al-sensitive) were cultured by hydroponics using the nutrient solution without $\mathrm{Al}^{3+}$ (as a Control) or with $1.0 \mathrm{mM} \mathrm{Al}^{3+}$ (as $\mathrm{Al}$ toxicity). The $\mathrm{Al}$ distribution and translocation were investigated by $\mathrm{CW}$ fragmentation to explore the primary Al-binding sites of citrus species. The study also examined the relative expression of genes associated with $\mathrm{Al}$ distribution, the kinetics analysis of $\mathrm{Al}$ adsorption and desorption, and FTIR analysis of the root CW of two citrus species. The objective of the study is to increase our understanding of the physiological mechanisms underlying the adaptation of citrus species to excessive levels of Al.

\section{Results}

\section{The Al distribution at the tissue level of citrus species}

As shown in Fig. $1.0 \mathrm{mM} \mathrm{Al}$ treatment significantly increased $\mathrm{Al}$ content in lateral roots (Fig. 1a) and primary roots (Fig. 1b) compared to the Control in seedlings of two citrus species. A significant increase of $\mathrm{Al}$ content was also found in the $\mathrm{Al}$-treated leaves and the stems in C. grandis seedlings (Fig. 1c and d). However, no significant difference in $\mathrm{Al}$ content was observed in the Al-treated leaves and stems of $C$. sinensis seedlings compared to the Control. The comparison between citrus species shows that the leaves and stems of C. grandis had remarkably higher $\mathrm{Al}$ content than $C$. sinensis under $\mathrm{Al}$ treatment. In contrast, $C$. sinensis lateral roots had a notably higher $\mathrm{Al}$ content than those of $C$. grandis under high $\mathrm{Al}$ concentration. Additionally, the $\mathrm{Al}$ content at tissue level was found to be lateral roots > primary roots $>$ leaves $>$ stems under $\mathrm{Al}$ stress.

\section{The Al distribution at $\mathrm{CW}$ fragments of citrus species}

The results of Fig. 2 show the Al content significantly increased in the Al-treated root CW of two citrus species compared to Control. The $\mathrm{Al}$ level in the root $\mathrm{CW}$ was about 8 to 10 times higher than the lateral roots under Al toxicity. Compared to C. grandis, C. sinensis had a significantly higher $\mathrm{Al}$ content in the Al-treated root $\mathrm{CW}$. Differentially, no significant difference of $\mathrm{Al}$ content was found among the CW residues after the removal of pectin from the root $\mathrm{CW}$ in two citrus species in both the control and the $\mathrm{Al}$ toxicity treatment.

\section{The relative expression of genes associated with Al transport and distribution}

The relative expression of genes involved in $\mathrm{Al}$ transport and distribution of two citrus species was presented in Fig. 3. Compared to the Control, Al toxicity upregulated the expression of Cs6g03670.1 (3 A) and Cg1g021320.1 (3B) significantly in roots of two citrus species. Besides, the relative expression level of 


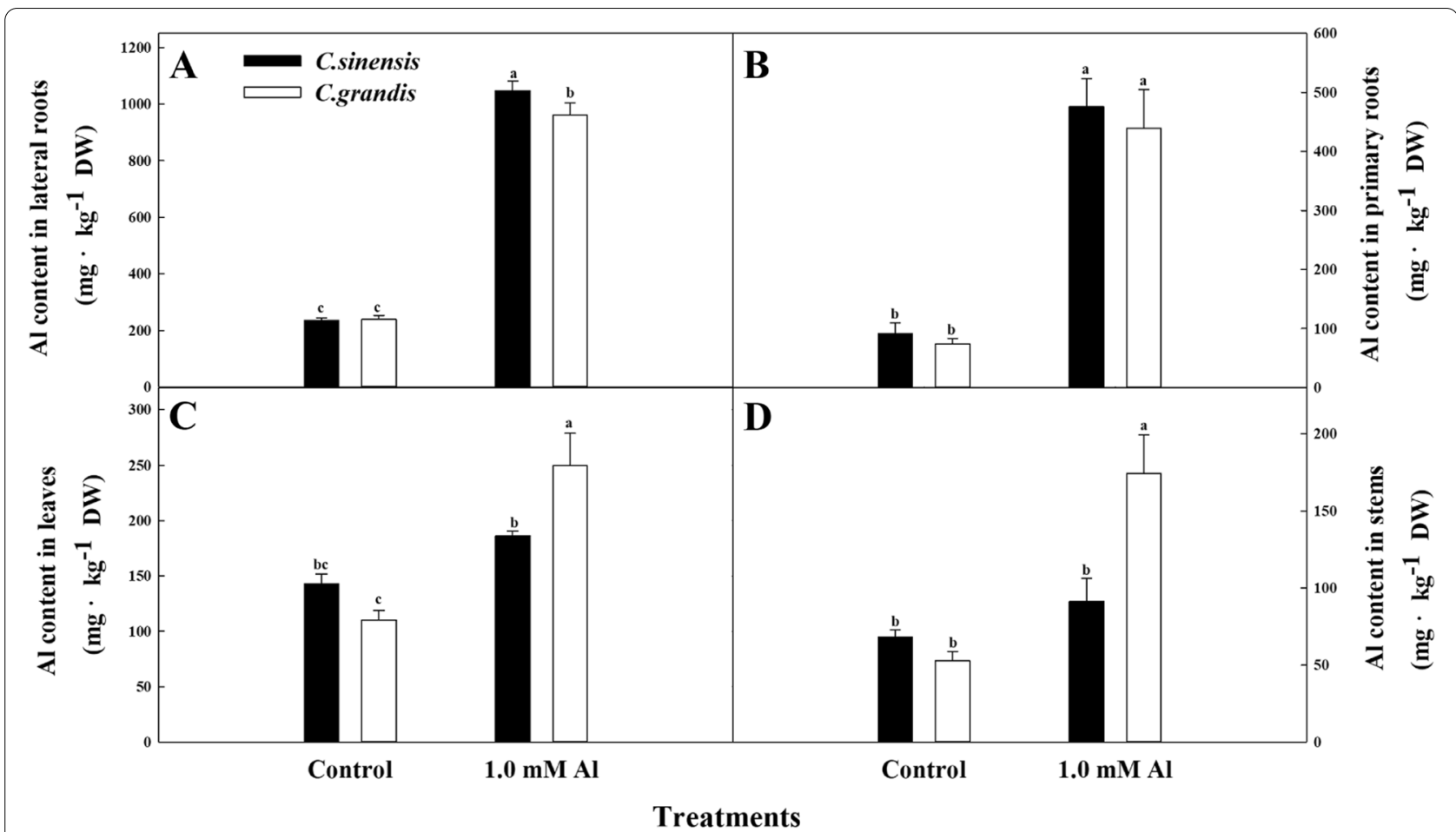

Fig. 1 The effects of Al toxicity on Al distribution in lateral roots $\mathbf{A}$, primary roots $\mathbf{B}$, leaves $\mathbf{C}$ and stems $\mathbf{D}$ of $\mathbf{C}$. sinensis and C. grandis seedlings. Seedlings of $C$. sinensis and C. grandis were treated with nutrient solution (Control, $\mathrm{pH} 4.3$ ) or supplemented by $1.0 \mathrm{mM} \mathrm{Al}$ l $^{3+}(1.0 \mathrm{mM} \mathrm{Al}$ toxicity, pH 4.3) for 21 days. The values represent mean $\pm \operatorname{SE}(N=5)$. Significant differences $(p \leq 0.05)$ between treatments are indicated by different letters

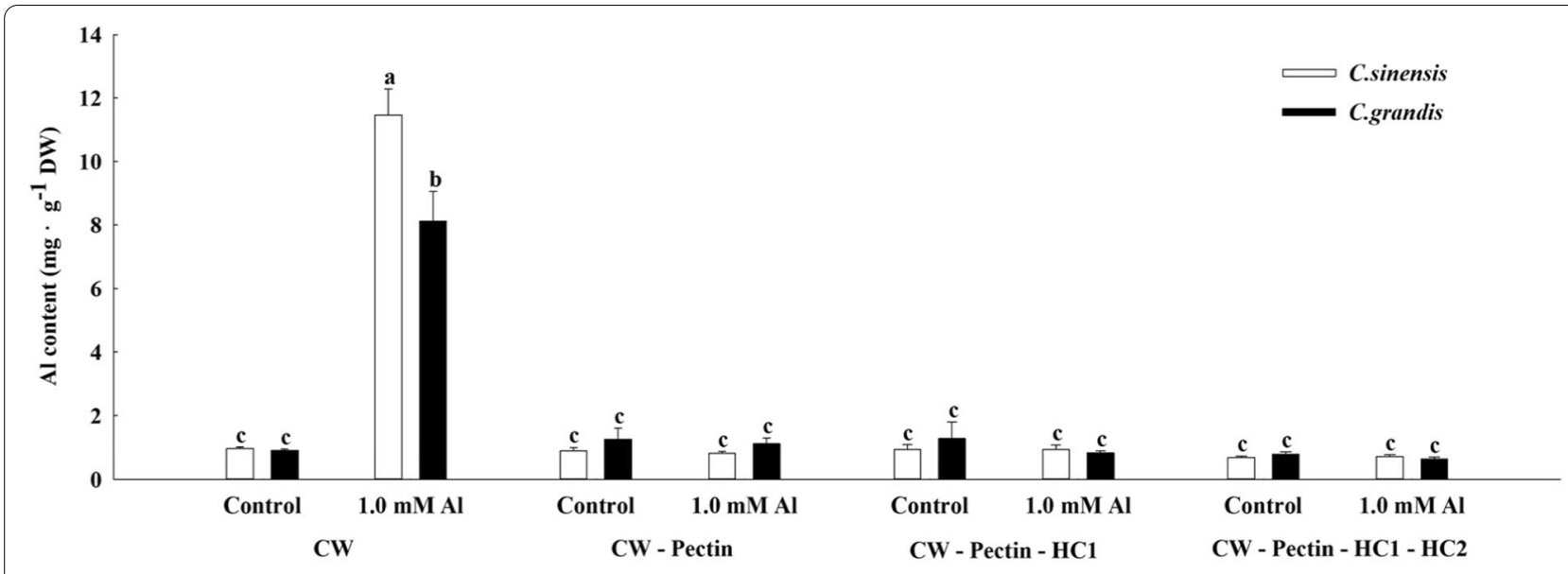

Fig. 2 The Al content in different root CW components of C. sinensis and C. grandis seedlings. Seedlings of $C$. sinensis and C. grandis were treated with nutrient solution (Control, pH 4.3) or supplemented by $1.0 \mathrm{mM} \mathrm{Al}{ }^{3+}(1.0 \mathrm{mM}$ Al toxicity, pH 4.3) for 21 days. Dry lateral roots were used for CW extraction and Al quantification. The values represent mean \pm SE $(N=5)$. Significant differences $(p \leq 0.05)$ between treatments are indicated by different letters

Cs6g03670.1 and Cg1g021320.1 was significantly higher in C. grandis compared to C. sinensis under Al toxicity. Differentially, the relative expression of Cs3g18690.1 was upregulated in $C$. sinensis while downregulated remarkably in C. grandis (3 C). Compared to Control, no significant difference in the relative expression of Cs6g05460.1 was found in Al-treated roots of C. sinensis. However, the $\mathrm{Al}$ toxicity upregulated the relative 


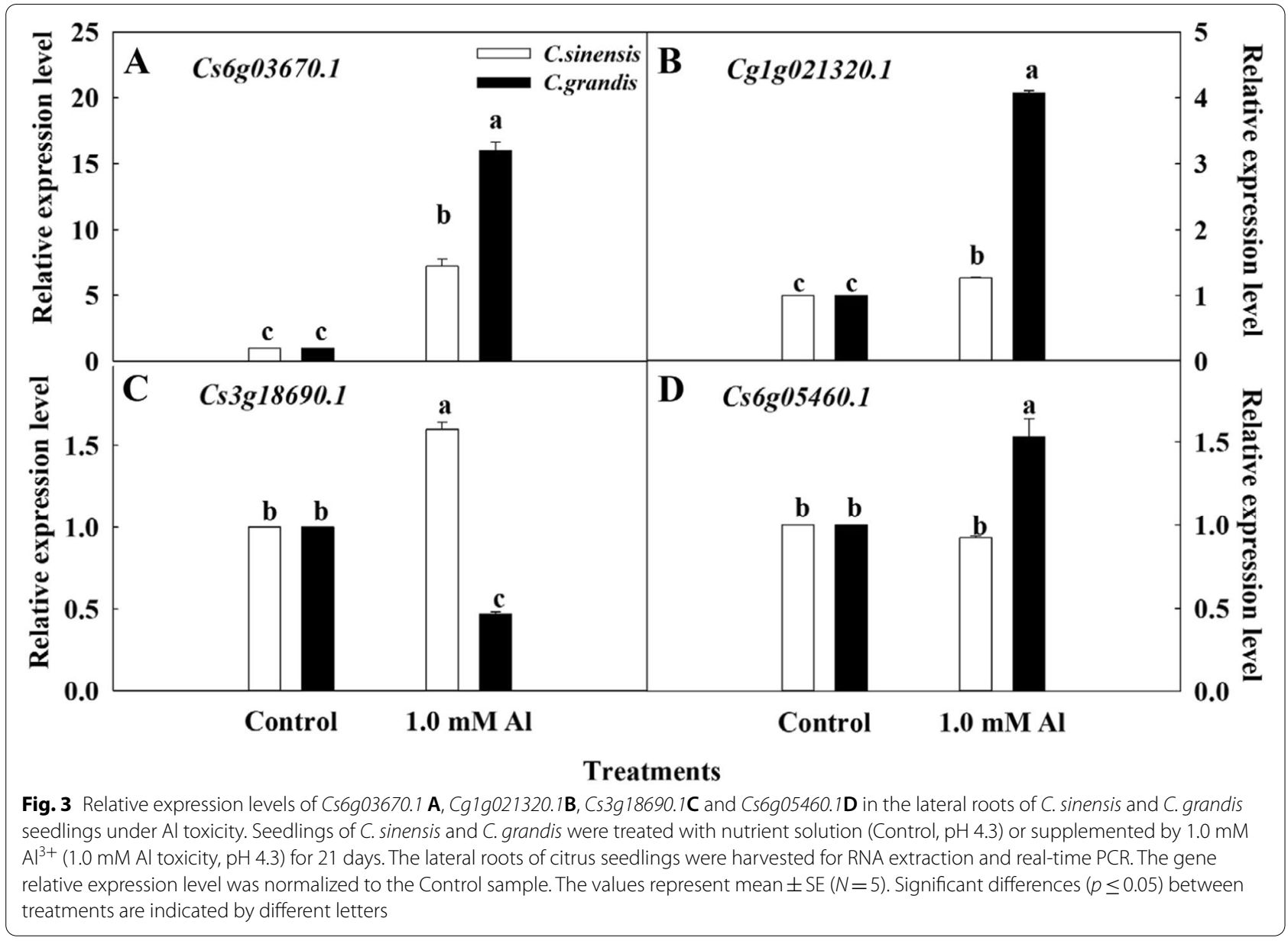

expression Cs6g05460.1 in C. grandis roots compared to Control (3D).

\section{The Al adsorption and desorption analysis of root CW of citrus species}

The CW of the lateral root of two citrus species was extracted for kinetics analysis of $\mathrm{Al}$ adsorption and desorption within 600 min. As shown in Fig. 4a, Al uptake in the root $\mathrm{CW}$ of $C$. sinensis was higher in comparison to $C$. grandis, indicating the root CW of C. sinensis had a higher capacity for $\mathrm{Al}$ binding than $C$. grandis. Moreover, the relative desorption rate in Fig. $4 \mathrm{~b}$ showed that the lateral root $C W$ of $C$. sinensis had a higher Al-binding rate than that of $C$. grandis. By comparison, $C$. sinensis had a lower $\mathrm{Al}$ desorption rate compared to $C$. grandis up to $600 \mathrm{~min}$.

\section{The FTIR spectra of lateral root CW}

The alterations of CW composition and structure by Al toxicity were revealed by FTIR analysis (Fig. 5). The wavenumber of spectra from two citrus species and related assignments were listed in Table 1 . The results show that the root CW of the Control from two citrus species had almost the same band position, indicating the similar composition of chemical groups of the root CW. However, band positions shifted under Al toxicity differentially in two citrus species. For instance, the vibration located at $3400 \mathrm{~cm}^{-1}$ was moved to $3396 \mathrm{~cm}^{-1}$ in C. grandis by Al toxicity. The vibration was shifted from $2856 \mathrm{~cm}^{-1}$ to $2858 \mathrm{~cm}^{-1}$ in C. sinensis and $2858 \mathrm{~cm}^{-1}$ to $2860 \mathrm{~cm}^{-1}$ in C. grandis by Al toxicity. It was also strikingly to find that most band positions from $1800 \mathrm{~cm}^{-1}$ to $800 \mathrm{~cm}^{-1}$, associated with polysaccharides, amide and ester, were shifted in both of two citrus species by $\mathrm{Al}$ toxicity. Apart from the band position shift, the relative absorbance at most band positions was also decreased by $\mathrm{Al}$ toxicity in two citrus species compared to the Control (Fig. 5a and b). The digital subtraction spectra were generated by subtracting the Al-treated spectra from the Control spectra of the $\mathrm{CW}$ of two citrus species, respectively. As found in Fig. 5c, the band intensity of the C. grandis was stronger than that of $C$. grandis overall. The OPLS-DA (orthogonal partial least-squares 


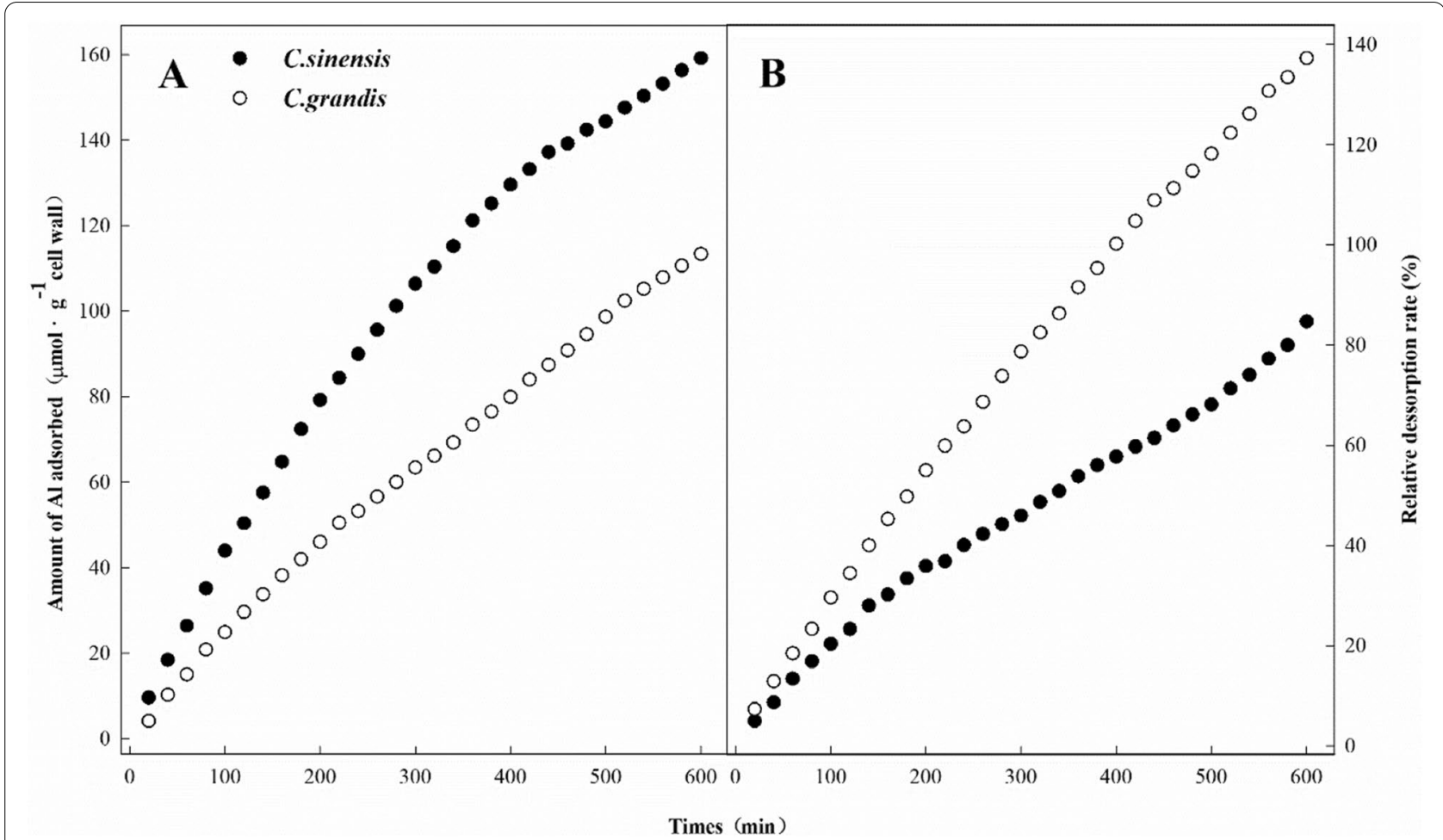

Fig. 4 The Al Adsorption A and desorption B kinetics of lateral root CW of C. sinensis and C. grandis. Seedlings of C. sinensis and C. grandis were treated with nutrient solution (Control, pH 4.3) for 21 days. The lateral root CW samples were extracted for Al adsorption and desorption kinetics analysis within $600 \mathrm{~min}$

Table 1 The infrared absorption frequencies of the CW and tentative assignment. Seedlings of C. sinensis and C. grandis were treated with nutrient solution (Control, pH 4.3) or supplemented by $1.0 \mathrm{mM} \mathrm{Al}{ }^{3+}(1.0 \mathrm{mM}$ Al toxicity, $\mathrm{pH}$ 4.3). The lateral root CW samples were extracted for FTIR spectra analysis

\begin{tabular}{|c|c|c|c|c|c|}
\hline \multicolumn{4}{|c|}{ Wavenumber $\left(\mathrm{cm}^{-1}\right)$} & \multirow[t]{3}{*}{ Tentative Assignment } & \multirow[t]{3}{*}{ Reference } \\
\hline \multicolumn{2}{|c|}{ C. sinensis } & \multicolumn{2}{|c|}{ C. grandis } & & \\
\hline Control & Al toxicity & Control & Al toxicity & & \\
\hline 3400 & 3400 & 3400 & 3396 & OH stretching & [27] \\
\hline 2924 & 2926 & 2924 & 2926 & $\mathrm{CH}$ asymmetric stretching & [28] \\
\hline 2856 & 2858 & 2858 & 2860 & CH symmetric stretching & [28] \\
\hline 1740 & 1740 & 1740 & 1740 & $\mathrm{C}=\mathrm{O}$ stretching of ester & [28] \\
\hline 1649 & 1649 & 1649 & 1649 & $\mathrm{C}=\mathrm{O}$ stretching of amide $\mathrm{I}$ band & [29] \\
\hline 1545 & 1543 & 1543 & 1543 & $\mathrm{NH}$ bending and $\mathrm{CN}$ stretching of amide II band & [29] \\
\hline 1514 & 1518 & 1520 & 1520 & $\mathrm{NH}$ bending and $\mathrm{CN}$ stretching of amide II band & [30] \\
\hline 1427 & 1427 & 1427 & 1427 & $\mathrm{CH} 2$ symmetric deformation & [31] \\
\hline 1375 & 1375 & 1373 & 1373 & COO- symmetric stretching and aliphatic group vibration & [32] \\
\hline 1329 & 1331 & 1327 & 1331 & $\mathrm{C}-\mathrm{O}$ & [33] \\
\hline 1246 & 1244 & 1246 & 1244 & $\mathrm{C}=\mathrm{O}$ stretching or $\mathrm{NH}$ bending of amide III bands & [32] \\
\hline 1155 & 1153 & 1153 & 1153 & phosphoryl group & [28] \\
\hline 1103 & 1101 & 1103 & 1105 & $\mathrm{C}=\mathrm{O}$ stretching, alclhol hydroxyl, ether or ester base & [29] \\
\hline 1059 & 1047 & 1059 & 1054 & C-OH stretching of alcoholic groups and carboxylic acids & [34] \\
\hline 899 & - & 899 & 906 & $\beta$-linkage between two glucose units & [31] \\
\hline
\end{tabular}



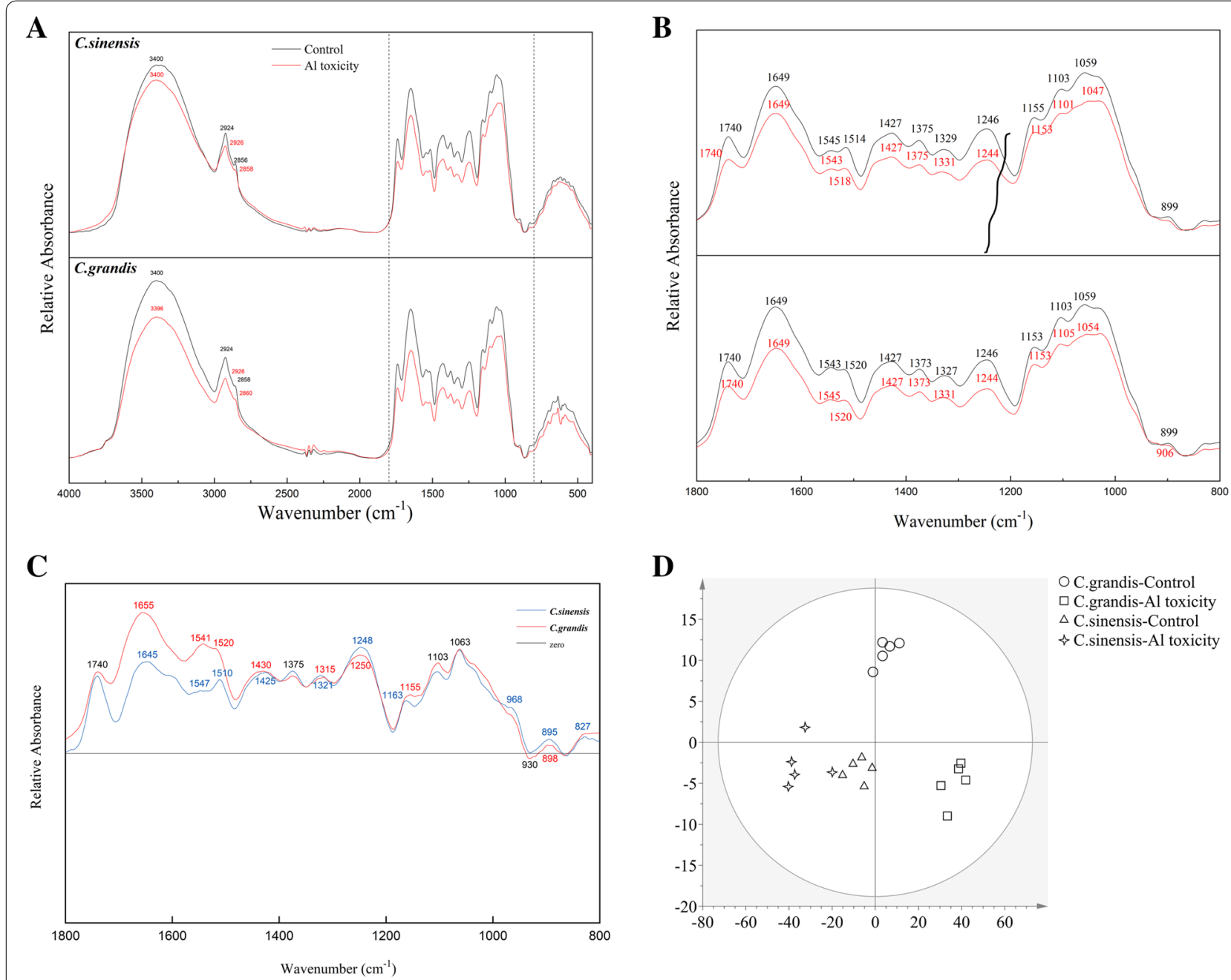

$\mathbf{D}$

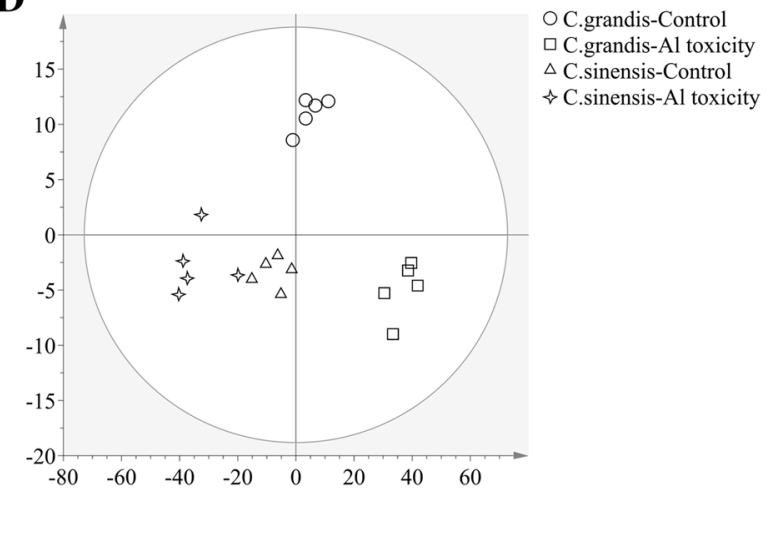

Fig. 5 The FTIR spectra of the lateral root CW in the region of $4000-500 \mathrm{~cm}^{-1} \mathbf{A}, 1800-800 \mathrm{~cm}^{-1} \mathbf{B}$, digital subtraction spectra C and the OPLS-DA of relative absorbance $\mathbf{D}$ of two citrus species. Seedlings of $\mathbf{C}$. sinensis and C. grandis were treated with nutrient solution (Control, $\mathrm{pH}$ 4.3) or supplemented by $1.0 \mathrm{mM} \mathrm{Al}{ }^{3+}(1.0 \mathrm{mM}$ Al toxicity, $\mathrm{pH}$ 4.3). The lateral root CW samples were extracted for FTIR spectra analysis. The digital spectra represent Control CW minus Al toxic-CW. The values represent mean $\pm \mathrm{SE}(\mathrm{N}=5)$

discrimination analysis) on the relative absorbance also reflected a more apparent separation between the Control and Al-toxic CW of C. grandis than C. sinensis (Fig. 5d).

\section{Discussion}

Citrus fruit trees are superbly adapted to the acid soils with potentially high concentrations in south China [21]. Understanding of $\mathrm{Al}$ partition and mobilization in vivo is pivotal to revealing the mechanism of $\mathrm{Al}$ tolerance of citrus species. Moreover, discerning $\mathrm{Al}$ binding sites in citrus species is of great significance in the development of $\mathrm{Al}$ mitigation strategies. The present study addressed these challenges. Hydroponic culture has been widely used to explore the ion behavior of citrus species $[35,36]$.
Compared to our previous study in sandy culture with a $1.0 \mathrm{mM} \mathrm{Al}$ treatment for 18 weeks [23], the present 21 days' hydroponic culture of citrus species resulted in almost the same $\mathrm{Al}$ level in leaves, indicating a reliable treatment for this study.

It has been shown that $\mathrm{Al}$-induced phytotoxicity has many target sites from the apoplast to symplast in higher plants [37]. Accordingly, plant species vary in Al-tolerance and have evolved different strategies to cope with $\mathrm{Al}$ toxicity based on $\mathrm{Al}$ distribution and translocation. Plant species native to acid soils are often found to retain excess $\mathrm{Al}$ in insensitive roots, protecting leaves from metabolic disruption [38]. For instance, Kopittke et al. [13] reported that the Al-tolerant wheat accumulated more 
than four times of $\mathrm{Al}$ in roots compared to the sensitive line. Similarly, the higher $\mathrm{Al}$ content on the root apex was also observed in Al-tolerant common bean compared to an Al-sensitive genotype [39]. The present results support a greater accumulation of $\mathrm{Al}$ in roots under $\mathrm{Al}$ stress compared to shoots in citrus species (Fig. 1). Furthermore, the results also demonstrated that a significantly higher $\mathrm{Al}$ storage in lateral roots but significantly lower $\mathrm{Al}$ content transported to the shoots in C. sinensis compared to C. grandis under $\mathrm{Al}$ stress. Likewise, the higher $\mathrm{Al}$ translocation of $C$. grandis than C. sinensis was also found in $1.0 \mathrm{mM} \mathrm{Al}$-treated citrus seedlings under 18 weeks' sandy culture [11]. The relative expression level of genes directly involved in $\mathrm{Al}$ transport of citrus species indicated lower expression of Cs6g03670.1(ALS3) and Cg1g021320.1(Nramp6) could result in less Al transport from roots to shoots in C. sinensis compared to C. grandis (Fig. $3 \mathrm{~A}$ and $3 \mathrm{~B}$ ), which was in line with our previous investigation [40]. However, the $\mathrm{Al}$ stress within 21 days in the present study did not significantly affect the biomass accumulation of two citrus species (data not shown). With the stress duration increased to 15 weeks, the $C$. sinensis seedlings had remarkably higher biomass accumulation than C. grandis in both leaves and roots (Additional file 1: Figure S1). Conclusively, the relatively higher $\mathrm{Al}$ tolerance of $C$. sinensis is related to less $\mathrm{Al}$ translocation from the roots to shoots.

The plant root $\mathrm{CW}$ is the first defense against $\mathrm{Al}$ toxicity. Clarkson et al. [41] revealed that over $85 \%$ of $\mathrm{Al}$ accumulated on the $\mathrm{CW}$ of barley roots, and for woody plants, more than $88 \%$ of total $\mathrm{Al}$ was localized in the root CW of the conifer [42]. In the present study, the CW of citrus lateral roots accumulates about 8 to 10 times higher $\mathrm{Al}$ content than lateral roots, indicating the prominent roles of the root $\mathrm{CW}$ in $\mathrm{Al}$ immobilization of citrus species. Interestingly, the ratio of $\mathrm{CW}$-binded $\mathrm{Al}$ is very close to the finding of $\mathrm{Al}$-treated tea (Camellia sinensis) roots [43]. Moreover, the comparison of $\mathrm{Al}$ distribution in $\mathrm{CW}$ fractions suggests pectin has the greatest affinity for $\mathrm{Al}$ of $\mathrm{CW}$ polysaccharides in citrus roots. The contribution of pectin in $\mathrm{Al}$ sequestration was also reported in rice roots [44]. Li et al. [45] proposed that a high density of carboxylic groups on the pectin contributes to $\mathrm{Al}$ binding. Further studies regarding pectin content and related structural deformation of roots under $\mathrm{Al}$ stress of citrus species are needed to reveal the role of pectin in $\mathrm{Al}$ detoxification.

Ma et al. [46] reported that the $\mathrm{CW}$ of $\mathrm{Al}$ sensitive wheat had higher $\mathrm{Al}$ retention than $\mathrm{Al}$ tolerant cultivar under $10 \mu \mathrm{M} \mathrm{Al}$ within a $9 \mathrm{~h}$ exposure time. By contrast, we observed that a remarkably higher $\mathrm{Al}$ content in the $\mathrm{CW}$ of $C$. sinensis lateral roots than that of $C$. grandis (Fig. 2), which is consistent with the higher $\mathrm{Al}$ content of lateral roots in C. sinensis than C. grandis. Therefore, we propose that the $\mathrm{Al}$ distribution pattern in higher plants depends on the toxic intensity, such as $\mathrm{Al}$ level and stress duration. For example, the Al tolerant cultivar exclude $\mathrm{Al}$ encountering weak $\mathrm{Al}$ stress, which resulted in less $\mathrm{Al}$ accumulation. However, when the $\mathrm{Al}$ exclusion is not enough for $\mathrm{Al}$ detoxification, the excessive $\mathrm{Al}$ will be transported and redistributed in vivo, such as $\mathrm{Al}$ stabilization on the roots or CW.

The adsorption and desorption kinetics demonstrated that the root $\mathrm{CW}$ of $C$. sinensis, an Al-tolerant species, had a higher $\mathrm{Al}$ affinity than C. grandis (Fig. 4). By contrast, the root $\mathrm{CW}$ of $C$. grandis exhibited a lower $\mathrm{Al}$ adsorption and a higher $\mathrm{Al}$ desorption, indicating less tight Al-binding on the root $\mathrm{CW}$, which would facilitate higher $\mathrm{Al}$ translocation from apoplast to symplast. Therefore, we infer that Al-tolerant woody plants tend to retain excess $\mathrm{Al}$ on the root $\mathrm{CW}$ to diminish $\mathrm{Al}$ translocation owing to their high retention capacity of the root systems. Besides, the Al binding firmly on roots is economical for $\mathrm{Al}$ resistance considering the energy cost during $\mathrm{Al}$ translocation. The findings of the present study also implied that organic material prepared from CWs is promising in alleviating the $\mathrm{Al}$ toxicity of the citrus plants in acidic red soils.

The Al binding resulted in modification of the root CW, which could be assessed by FTIR analysis $[47,48]$. The results of this study show that almost no new characteristic peaks emerged indicating less effect of $\mathrm{Al}$ toxicity on the types of functional groups on the $\mathrm{CW}$ by $\mathrm{Al}$ toxicity overall in two citrus species. The modification of $\mathrm{CW}$ by $\mathrm{Al}$ stress is mainly dependent on the abundance of chemical groups on the root $\mathrm{CW}$ of citrus species. For instance, the spectra at $3400 \mathrm{~cm}^{-1}$ (-OH stretching), was shifted to $3396 \mathrm{~cm}^{-1}$ under $\mathrm{Al}$ stress in C. grandis, suggesting the changes in hydrogen-bonding mode and the damaging of connections between $\mathrm{CW}$ components by $\mathrm{Al}$ toxicity (Table 1). The results support less $\mathrm{Al}$ tolerance of C. grandis than C. sinensis by considering the flexible deformation of hydrogen bonds between molecules [26]. Also, a previous study has shown that the absorbance at 1740 and $1649 \mathrm{~cm}^{-1}$ represents the absorption of the esterified and non-esterified carboxyl groups of pectin, respectively [49]. The present results of downregulated relative absorbance at $1740 \mathrm{~cm}^{-1}$ and $1649 \mathrm{~cm}^{-1}$ were coincident with significantly higher $\mathrm{Al}$ accumulation in the pectin (Fig. $5 \mathrm{C}$ ), suggesting the role of $\mathrm{CW}$ pectin in Al-binding under $\mathrm{Al}$ toxicity. Besides, it is also interesting to find that the vibrations from $1200 \mathrm{~cm}^{-1}$ to $900 \mathrm{~cm}^{-1}$ (Table 1), which belong to the polysaccharide fingerprint region [50], shifted and decreased under $\mathrm{Al}$ toxicity. The results indicated that the altered structure and content of $\mathrm{CW}$ polysaccharides under $\mathrm{Al}$ toxicity would affect the $\mathrm{Al}$ 
binding on the root of citrus species. Both of the digital subtraction spectra (Fig. 5c) and the OPLS-DA (Fig. 5c) of relative absorbance in two citrus species supported a greater alteration of the $\mathrm{CW}$ in $C$. grandis compared to $C$. sinensis, such as more severe damage under $\mathrm{Al}$ toxicity. Similarly, a higher relative absorbance of the upper leaves corresponding to a much obvious symptom of boron deficient orange seedlings compared to lower leaves has also been reported based on the FTIR analysis [35]. Further studies based on isotope labeling of $\mathrm{Al}$ and pectin deformation and polysaccharides quantification of the citrus root $\mathrm{CW}$ are needed to disclose the $\mathrm{Al}$ spatial and temporal distribution of $\mathrm{Al}$.

\section{Conclusions}

At the tissue level, citrus lateral roots were the primary Al-binding site under Al toxicity. At the subcellular level, the pectin of the CW was most abundant in the $\mathrm{Al}$-accumulation of citrus species. Compared to C. grandis, a less tolerant citrus species, $C$. sinensis had a higher $\mathrm{Al}$ retention on the root $\mathrm{CW}$ and a lower $\mathrm{Al}$ translocation efficiency from roots to shoots upon exposure to toxic levels of $\mathrm{Al}(1.0 \mathrm{mM} \mathrm{Al})$. Both the transcriptional regulation of genes related to $\mathrm{Al}$ transport and the structural modification of root $\mathrm{CW}$ contributed to the $\mathrm{Al}$ translocation of two citrus species. Future investigations on the $\mathrm{Al}$ partition and translocation mediated by $\mathrm{CW}$ modification are necessary to fully elucidate the mechanisms of $\mathrm{Al}$ tolerance in citrus species.

\section{Methods}

\section{Plant culture and treatments}

The citrus species 'Xuegan' [Citrus sinensis (L.) Osbeck] and 'Suanyou' [Citrus grandis (L.) Osbeck] used in the study were identified by Professor Lin-tong Yang of Fujian Agriculture and Forestry University (Fuzhou, China) and deposited as living materials for research purposes in the demonstration orchard of Fujian Academy of Forestry Sciences (FAFS). In December 2018, citrus fruits were harvested under the permission of Professor Xiang-xi Xiao in FAFS and stored in a fridge at $4{ }^{\circ} \mathrm{C}$. For germination, the seeds of $C$. sinensis and C. grandis were sown in a plastic tray filled with clean river sand at the greenhouse in early April of 2019. Four weeks after germination, seedlings of uniform size (about $10 \mathrm{~cm}$ ) were transferred to black tanks containing nutrient solution and aerated for 30 min every two hours. The nutrient solution contained $1 \mathrm{mM} \mathrm{KNO}, 1 \mathrm{mM} \mathrm{Ca}\left(\mathrm{NO}_{3}\right)_{2}$, $0.1 \mathrm{mM} \mathrm{KH}_{2} \mathrm{PO}_{4}, 0.5 \mathrm{mM} \mathrm{MgSO}_{4}, 10 \mu \mathrm{M} \mathrm{H}_{3} \mathrm{BO}_{3}, 2 \mu \mathrm{M}$
$\mathrm{MnCl}_{2}, 2 \mu \mathrm{M} \mathrm{ZnSO}{ }_{4}, 0.5 \mu \mathrm{M} \mathrm{CuSO}_{4}, 0.065 \mu \mathrm{M}\left(\mathrm{NH}_{4}\right)$ $\mathrm{Mo}_{7} \mathrm{O}_{24}$ and $20 \mu \mathrm{M}$ Fe-EDTA. The $\mathrm{pH}$ of the nutrient solution was adjusted to 4.30 using $1 \mathrm{M} \mathrm{HCl}$ or $\mathrm{NaOH}$ and was replaced every two days. Three months after transplanting, the plants were subjected to the treatments with 0 (Control) or $1.0 \mathrm{mM} \mathrm{Al}$ (Al toxicity) in the nutrient solution described above ( $\mathrm{pH} 4.30)$. The samples of citrus leaves, stems, primary roots and lateral roots were divided and collected 21 days after treatments when visible leaf chlorosis appeared on $\mathrm{Al}$-treated C. grandis leaves.

\section{Quantification of Al at the tissue level}

The leaves, stems, primary roots and lateral roots of citrus species were dried and digested in $\mathrm{HNO}_{3} / \mathrm{HClO}_{4}$ $(5: 1, \mathrm{v} / \mathrm{v})$, and $\mathrm{Al}$ content was quantified according to Hsu [51].

\section{Quantification of Al on CW fractions of citrus lateral roots}

The crude CW of citrus lateral roots was extracted according to Zhong and Lauchli [52] with modifications. Briefly, about $50 \mathrm{mg}$ citrus lateral root was powdered and polled into a centrifuge tube with $5 \mathrm{~mL}$ ice-cold $75 \%$ ethanol for $20 \mathrm{~min}$ on ice. The samples were then centrifuged at $1000 \mathrm{~g}$ for $10 \mathrm{~min}$. The supernatant was discarded, and the resulting pellets were centrifugated at $17,000 \mathrm{~g}$ for $10 \mathrm{~min}$ three times with $5 \mathrm{~mL} 80 \%$ ethanol, methanol-chloroform mixture $(1: 1, \mathrm{v} / \mathrm{v})$ and acetone, respectively. The final pellets were pooled as crude $\mathrm{CW}$ after being dried and weighed.

The dry crude CW from the lateral roots of citrus seedlings was further fractioned according to Yang et al. [17] Briefly, the dry crude $\mathrm{CW}$ was added into ammonium oxalate (containing $\left.0.1 \% \mathrm{NaBH}_{4}, \mathrm{pH}=4.0\right)(5 \mathrm{mg}$ $\mathrm{CW} / 1 \mathrm{~mL}$ solution) in a boiling water bath for one hour and centrifuged at $17,000 \mathrm{~g}$ for $10 \mathrm{~min}$ for three times to remove the pectin, the resulting pellet (CW-pectin) was pooled and dried. The CW-pectin fraction was extracted by $4 \% \mathrm{KOH}$ (containing $0.1 \% \mathrm{NaBH}_{4}$ ) or $24 \%$ $\mathrm{KOH}$ (containing $0.1 \% \mathrm{NaBH}_{4}$ ) under room temperature three times for $24 \mathrm{~h}$ in total to further remove the hemicellulose 1 (HC-1) and hemicellulose 2 (HC-2). The pooled pellets were $\mathrm{CW}$-pectin fractions without $\mathrm{HC} 1$ (CW-pectin-HC1) and $\mathrm{HC} 2$ (CW-pectin-HC1-HC2), respectively. The $\mathrm{Al}$ content of the $\mathrm{CW}$ and $\mathrm{CW}$ fractions (CW-pectin, CW-pectin- $\mathrm{HC} 1$ and $\mathrm{CW}$-pectin-HC1HC2) was quantified according to the method described above. The $\mathrm{Al}$ content of $\mathrm{CW}$ and $\mathrm{CW}$ fractions was expressed as $\mathrm{mg} \cdot \mathrm{g}^{-1} \mathrm{DW}$ (dry weight) of lateral roots. 
Table 2 Genes and their primers for relative expression analysis using RT-qPCR

\begin{tabular}{|c|c|c|}
\hline Accession number & Description & Forward $(F)$ and reverse $(R)$ primer sequences \\
\hline Cs6g03670.1 & Aluminum Sensitive 3 (ALS3) & $\begin{array}{l}\text { F: 5'TGCTGCTGGCTGTCCTGTT 3' } \\
\text { R: 5'TGCTTTGTTGCCTGTCTCG 3' }\end{array}$ \\
\hline Cg1g021320.1 & Metal transporter Nramp6 & $\begin{array}{l}\text { F: 5'TAACTGGAACTTATGCGGGACA 3' } \\
\text { R: } 5^{\prime} \text { CTGCCATTGCCGAAAAC } 3^{\prime}\end{array}$ \\
\hline Cs3g18690.1 & Heavy metal transport/detoxification superfamily protein & $\begin{array}{l}\text { F: 5'GTGGACTTGAAGCAGCAGAA 3' } \\
\text { R: 5'TGAGCACGCATTAGGATTTT 3' }\end{array}$ \\
\hline Cs6g05460.1 & Heavy metal transport/detoxification superfamily protein & $\begin{array}{l}\text { F: 5'TACCCTCTGCCCCTTGTTC 3' } \\
\text { R: 5'GCTAATGGCTTGGAGTTGGAT 3' }\end{array}$ \\
\hline Cs1g05000.1 & Reference gene as internal control & $\begin{array}{l}\text { F: 5'TTTACCACCACAGCCGAACG 3' } \\
\text { R: 5'TGGAGCCACGACCTTGAT 3' }\end{array}$ \\
\hline
\end{tabular}

\section{The relative expression analysis of genes involved in Al translocation}

Lateral roots of two citrus species were harvested for the relative expression analysis of genes (Cs6g03670.1, Cg1g021320.1, Cs3g18690.1 and Cs6g05460.1) involved in Al translocation according to $\mathrm{Wu}$ et al. [40]. Briefly, total RNA in lateral roots was extracted using TRIzol reagent (Invitrogen, Carlsbad, CA, USA). The Fastking FIRST STRAND cDNA synthesis kit (Tiangen, Beijing, China) was used for cDNA synthesis following the manufacturer's instructions. RT-qPCR was performed using 2 RealStar Green Fast Mixture (Genstar, China) in CFX96 ${ }^{\mathrm{TM}}$ Real-Time System according to the manufacturer's instructions. The $20 \mu \mathrm{L}$ reaction system contained 10 $\mu \mathrm{L}$ iQ SYBR green supermix, $0.5 \mu \mathrm{L}$ each of $10 \mu \mathrm{M}$ primers, $1.0 \mu \mathrm{L}(5 \mathrm{ng})$ DNA template, and $8.0 \mu \mathrm{L}$ RNAasefree $\mathrm{H}_{2} \mathrm{O}$. The program consisted of initial denaturation at $95{ }^{\circ} \mathrm{C}$ for $2 \mathrm{~min}$, followed by 40 cycles of $95{ }^{\circ} \mathrm{C}$ for $10 \mathrm{~s}, 57^{\circ} \mathrm{C}$ for $35 \mathrm{~s}$ and $72{ }^{\circ} \mathrm{C}$ for $30 \mathrm{~s}$. Citrus genes actin (Cs1g05000.1) was used as internal references [53]. The primers were designed using Primer Premier 5 software (Premier Biosoft Ltd., Palo Alto, CA, USA) based on the gene sequences from Citrus Genome Database (https:// www.citrusgenomedb.org/) and listed in Table 2. The data were processed by the method of $2^{-\Delta \Delta C T}$ according to Livak and Schmittgen [54]. The gene relative expression was normalized to Control. The fold changes of each gene were used for statistical analysis. There were 4 biological replications with 3 technical replicates of each.

\section{Al adsorption and desorption kinetics}

The $\mathrm{Al}$ adsorption and desorption kinetics were performed according to Zheng et al. [55] with modifications. Briefly, the adsorption solution of $0.5 \mathrm{mM} \mathrm{Al}^{3+}$ in $0.5 \mathrm{mM} \mathrm{CaCl}_{2}$ (pH 4.30) was pumped by a peristaltic pump at $0.2 \mathrm{~mL} / \mathrm{min}$ through a $2 \mathrm{~mL}$ column loaded with $10 \mathrm{mg}$ root $\mathrm{CW}$ for $\mathrm{Al}$ adsorption. The solution after $\mathrm{CW}$ adsorption was then collected by a fraction collector at
20 min intervals until the $\mathrm{Al}$ content was equal to the adsorption solution. The residue $\mathrm{Al}^{3+}$ left in the system was washed by $0.5 \mathrm{mM} \mathrm{CaCl}_{2}(\mathrm{pH} 4.5)$ at $0.6 \mathrm{~mL} / \mathrm{h}$ for $1 \mathrm{~h}$ before $\mathrm{Al}$ desorption by $2.5 \mathrm{mM} \mathrm{CaCl}_{2}(\mathrm{pH} 4.30)$ at $0.2 \mathrm{~mL} / \mathrm{h}$ until the $\mathrm{Al}$ concentration in the collector was below the detection limit. Finally, the Al content in the fraction collector was quantified, and the kinetics were analyzed within $600 \mathrm{~min}$. The $\mathrm{Al}$ absorption and desorption kinetics were performed three times independently.

\section{FTIR spectra analysis}

$2 \mathrm{mg}$ dry $\mathrm{CW}$ of citrus lateral root was mixed with $200 \mathrm{mg} \mathrm{KBr}$ and pressed into a disk by FW-5 A Pressor. The IR spectra of CWs ranging from $4000-400 \mathrm{~cm}^{-1}$ were recorded using Vertex 70 spectrometer with a resolution of $4 \mathrm{~cm}^{-1}$ and 32 scans per sample. The obtained spectra were normalized and baseline-corrected by OPUS management software before being exported to Excel. The data of FTIR spectra were processed by Origin Pro 2020b (OriginLab Corporation, USA). The OPLSDA was performed in SIMCA 14.1 (Umetrics AB, Umea, Sweden).

\section{Data analysis}

Data analysis was performed by two-way analysis of variance, and significant differences $(P<0.05)$ among treatments were statistically evaluated by two-way ANOVA using Duncan's test, using the SPSS 16.0 (SPSS Corp., Chicago, IL, USA). All the values are presented as means \pm SE. Figures except OPLS-DA were generated by using Sigmaplot 12.0.

\section{Abbreviations}

ALS3: Al sensitive 3; CW: cell wall; DW: dry weight; FTIR: Fourier transform infrared spectroscopy; HC: hemicellulose; Nramp: natural resistance-associated macrophage protein; OPLS-DA: orthogonal partial least-squares discrimination analysis. 


\section{Supplementary Information}

The online version contains supplementary material available at https://doi. org/10.1186/s12870-022-03472-5.

Additional file 1: Figure S1. The effects of Al toxicity on the DWs of whole plants (A), roots (B), stems (C), leaves (D), shoots (E) and ratio of root/shoot (F) of $C$. sinensis and C. grandis seedlings. Seedlings of $C$. sinensis and $\mathrm{C}$. grandis were treated with nutrient solution (Control, $\mathrm{pH}$ 4.3) or supplemented by $0.5,1.0$ and $2.0 \mathrm{mM} \mathrm{Al}^{3+}(\mathrm{pH} 4.3)$ for 15 weeks. The values represent mean $\pm \operatorname{SE}(N=6)$. Significant differences $(p \leq 0.05)$ between treatments are indicated by different letters.

\section{Acknowledgements}

The authors thank Professor Richard G Donald (Dalhousie University, Halifax, Canada) for the linguistic assistance during the preparation of this manuscript.

\section{Authors' contributions}

$\mathrm{HZ}$ wrote the manuscript; $\mathrm{XL}$ analyzed the experimental results; ML prepared the figures and tables; $\mathrm{PH}$ carried out the experiments; NL designed the experiment; $\mathrm{ZH}$ revised the drafts of the manuscript; $\mathrm{LC}$ reviewed drafts of the manuscript. All authors read and approved the final manuscript.

\section{Funding}

This research was funded by the National Natural Science Foundation of China (31801950) and the Special Fund for Scientific and Technological Innovation of Fujian Agriculture and Forestry University (CXZX2019079S). The funders had no role in the design of the study and collection, analysis, and interpretation of data and in writing the manuscript.

\section{Availability of data and materials}

The DNA sequences are accessible in Citrus Genome Database (https://www. citrusgenomedb.org/). All data analyzed in this study are included in this published article and its additional files.

\section{Declarations}

\section{Ethics approval and consent to participate}

Not applicable.

\section{Consent for publication}

Not applicable.

\section{Competing interests}

The authors declare that they have no competing interests. The author LiSong Chen is a member of the editorial board of BMC Plant Biology.

\section{Author details}

${ }^{1}$ College of Resources and Environment, Fujian Agriculture and Forestry University, 350002 Fuzhou, China. ${ }^{2}$ College of Forestry, Guangxi University, 530004 Nanning, China.

Received: 11 June 2021 Accepted: 15 February 2022

Published online: 02 March 2022

\section{References}

1. Guo JH, Liu XJ, Zhang Y, Shen JL, Han WX, Zhang WF, Christie P, Goulding KWT, Vitousek PM, Zhang FS. Significant acidification in major Chinese croplands. Science. 2010;327(5968):1008-10.

2. Lindsay WL, Walthall PM. The solubility of aluminum in soils. In: The environmental chemistry of aluminum. Boca Raton: CRC Press; 2020. pp. 333-61.

3. Li J, Su L, Lv A, Li Y, Zhou P, An Y. MsPG1 alleviated aluminum-induced inhibition of root growth by decreasing aluminum accumulation and increasing porosity and extensibility of cell walls in alfalfa (Medicago sativa). Environ Exp Bot. 2020;175:104045.
4. Xia H, Riaz M, Zhang M, Liu B, El-Desouki Z, Jiang CC. Biochar increases nitrogen use efficiency of maize by relieving aluminum toxicity and improving soil quality in acidic soil. Ecotox Environ Safe. 2020;196:110531.

5. Kang DJ, Seo YJ, Futakuchi K, Vijarnsorn P, Ishii R. Effect of aluminum toxicity on flowering time and grain yield on rice genotypes differing in Al - tolerance. J Crop Sci Biotech. 2011;14(4):305-9.

6. Valle SR, Carrasco J, Pinochet D, Calderini DF. Grain yield, above-ground and root biomass of $\mathrm{Al}$ - tolerant and $\mathrm{Al}$ - sensitive wheat cultivars under different soil aluminum concentrations at field conditions. Plant Soil. 2009;318:299-310.

7. Yan L, Riaz M, Wu XW, Du CQ, Liu YL, Jiang CC. Ameliorative effects of boron on aluminum induced variations of cell wall cellulose and pectin components in trifoliate orange (Poncirus trifoliate (L.) Raf.) rootstock. Environ Pollu. 2018:240:764-74.

8. Li Y, Han MQ, Lin F, Ten Y, Lin J, Zhu DH, Guo P, Weng YB, Chen LS. Soil chemical properties, 'Guanximiyou' pummelo leaf mineral nutrient status and fruit quality in the southern region of Fujian province, China. J Soil Sci Plant Nut. 2015;15(3):615-28.

9. Lin ZY, Myhre DL. Citrus root growth as affected by soil aluminum level under field conditions. Soil Sci Soc Am J. 1990:54(5):1340-4.

10. Li D, Li X, Han QZ, Zhou YZ, Dong JL, Duan ZQ. Phosphorus application improved the yield of citrus plants grown for three years in an acid soil in the three gorges reservoir area. Sci Hortic. 2020;273:109596.

11. Guo P, Qi YP, Cai YT, Yang TY, Yang LT, Huang ZR, Chen LS. Aluminum effects on photosynthesis, reactive oxygen species and methylglyoxal detoxification in two citrus species differing in aluminum tolerance. Tree Physiol. 2018;38(10):1548-65.

12. Silva CM, Cavalheiro MF, Bressan ACG, Carvalho BMO, Banhos OFAA, Purgatto E, Harakava R, Tanaka FAO, Habermann G. Aluminum-induced high IAA concentration may explain the Al susceptibility in Citrus limonia. Plant Growth Regul. 2019:87(1):123-37.

13. Kopittke PM, MCKenna BA, Karunakaran C, Dynes JJ, Arthur Z, Gianoncelli A, Kourousias G, Menzies NW, Ryan PR, Wang P. Aluminum complexation with malate within the root apoplast differs between aluminum resistant and sensitive wheat lines. Front Plant Sci. 2017;8:1377.

14. Chen LS, Yang LT, Guo P, Jiang HX. Tang N.Aluminum toxicity and fruit nutrition. In: Fruit Crops. Amsterdam: Elsevier; 2020. p. 223-40.

15. Yang TY, Qi YP, Huang HY, Wu FL, Huang WT, Deng CL, Yang LT, Chen LS. Interactive effects of $\mathrm{pH}$ and aluminum on the secretion of organic acid anions by roots and related metabolic factors in Citrus sinensis roots and leaves. Environ Pollut. 2020;262:114303.

16. Li CX, Yan JY, Ren JY, Sun L, Xu C, Li GX, Ding ZJ, Zheng SJ. A WRKY transcription factor confers aluminum tolerance via regulation of cell wall modifying genes. J Integ Plant Biol. 2020;62(8):1176-92.

17. Yang JL, Zhu XF, Peng YX, Zheng C, Li GX, Liu Y, Shi YZ, Zheng SJ. Cell wall hemicellulose contributes significantly to Al adsorption and root growth in Arabidopsis. Plant Physiol. 2011;155(4):1885-92.

18. Ye Y, Dai CY, Gu LP, Qu Y, Yang XY, Chen Q, Liu DQ, Wang CX, Cui XM. Distribution pattern of aluminum in Panax notoginseng, a native medicinal plant adapted to acidic red soils. Plant Soil. 2018;423(1):375-84.

19. Larsen PB, Geisler MJ, Jones CA, Williams KM, Cancel JD. ALS3 encodes a phloem-localized $A B C$ transporter-like protein that is required for aluminum tolerance in Arabidopsis. Plant J. 2005:41(3):353-63.

20. Xia J, Yamaji N, Kasai T, Ma JF. Plasma membrane-localized transporter for aluminum in rice. P Natl Acad Sci. 2010;107(43):18381-5.

21. Guo P, Qi YP, Yang LT, Lai NW, Ye X, Yang Y, Chen LS. Root adaptive responses to aluminum-treatment revealed by RNA-Seq in two citrus species with different aluminum-tolerance. Front Plant Sci. 2017:8:330.

22. Jiang HX, Chen LS, Han S, Zhang JF, Lin JQ. Effects of Aluminum on the Growth of Young Citrus Seedlings. Chin Agric Sci Bull. 2009;25(04):167-70. (in Chinese).

23. Zhang $H$, Li XY, Chen LS, Huang ZR. The photosynthetic performance of two citrus species under long-term aluminum treatment. Photosynthetica. 2020;58(2):228-35.

24. Guo P, Qi YP, Huang WL, Yang LT, Huang ZR, Lai NW, Chen LS. Aluminumresponsive genes revealed by RNA-Seq and related physiological responses in leaves of two Citrus species with contrasting aluminumtolerance. Ecotox Environ Safe. 2018;158:213-22.

25. Jiang HX, Yang LT, Qi YP, Lu YB, Huang ZR, Chen LS. Root iTRAQ protein profile analysis of two citrus species differing in aluminum-tolerance in response to long-term aluminum-toxicity. BMC Genomics. 2015;16:949. 
26. Li H, Yang LT, Qi YP, Guo P, Lu YB, Chen LS. Aluminum toxicity-induced alterations of leaf proteome in two citrus species differing in aluminum tolerance. Int J Mol Sci. 2016;17(7):1180.

27. Iqbal M, Saeed A, Zafar SI. FTIR spectrophotometry, kinetics and adsorption isotherms modeling, ion exchange, and EDX analysis for understanding the mechanism of $\mathrm{Cd}^{2+}$ and $\mathrm{Pb}^{2+}$ removal by mango peel waste. J Hazard Mater. 2009;164(1):161-71.

28. Chen SH, Cheow YL, Ng SL, Ting ASY. Mechanisms for metal removal established via electron microscopy and spectroscopy: a case study on metal tolerant fungi Penicillium simplicissimum. J Hazard Mater. 2019;362:394-402.

29. Deng PY, Liu W, Zeng BQ, Qiu YK, Li LS. Sorption of heavy metals from aqueous solution by dehydrated powders of aquatic plants. Int J Environ Sci Te. 2013;10(3):559-66.

30. Sigee DC, Dean A, Levado E, Tobin MJ. Fourier - transform infrared spectroscopy of Pediastrum duplex: characterization of a micro - population isolated from a eutrophic lake. Eur J Phycol. 2002;37:19-26.

31. Abidi N, Hequet E, Cabrales L, Gannaway J, Wilkins T, Wells LW. Evaluating cell wall structure and composition of developing cotton fibers using Fourier transform infrared spectroscopy and thermogravimetric analysis. J Appl Polym Sci. 2008;107(1):476-86.

32. Farinella NV, Matos GD, Arruda MAZ. Grape bagasse as a potential biosorbent of metals in effluent treatments. Bioresource Technol. 2007:98(10):1940-6.

33. Saha PD, Chakraborty S, Chowdhury S. Batch and continuous (fixed bed column) biosorption of crystal violet by Artocarpus heterophyllus (jackfruit) leaf powder. Colloids Surf B. 2012;92:262-70.

34. Guibaud G, Tixier N, Bouju A, Baudu M. Relation between extracellular polymers' composition and its ability to complex $\mathrm{Cd}$, $\mathrm{Cu}$ and $\mathrm{Pb}$. Chemosphere. 2003;52(10):1701-10.

35. Liu GD, Dong XC, Liu LC, Wu LS, Jiang CC. Boron deficiency is correlated with changes in cell wall structure that lead to growth defects in the leaves of navel orange plants. Sci Hortic. 2014;176:54-62.

36. Yan L, Riaz M, Wu X, Du CQ, Liu YL, Lv B, Jiang CC. Boron inhibits aluminum-induced toxicity to citrus by stimulating antioxidant enzyme activity. J Environ Sci Heal C. 2018;36(3):,145-63.

37. Zheng SJ, Yang JL. Target sites of aluminum phytotoxicity. Biol Plant. 2005;49(3):321-31.

38. Watanabe T, Osaki M. Mechanisms of adaptation to high aluminum condition in native plant species growing in acid soils: a review. Commun Soil Sci Plan. 2002;33:1247-60.

39. Rangel AF, Rao IM, Horst WJ. Intracellular distribution and binding state of aluminum in root apices of two common bean (Phaseolus vulgaris) genotypes in relation to Al toxicity. Physiol Plant. 2009;135(2):162-73.

40. Wu YM, Wang YY, Zhou YF, Meng X, Huang ZR, Chen LS, Yang LT. Analysis of interacting proteins of aluminum toxicity response factor ALS3 and CAD in Citrus. Int J Mol Sci. 2019;20(19):4846.

41. Clarkson DT. Interactions between aluminium and phosphorus on root surfaces and cell wall material. Plant Soil. 1967;27(3):347-56.

42. Heim A, Brunner I, Frey B, Frossard E, Luster J. Root exudation, organic acids, and element distribution in roots of Norway spruce seedlings treated with aluminum in hydroponics. J Plant Nutr Soil Sc. 2001:164(5):519-26.

43. Hajiboland R, Bastani S, Bahrami-Rad S, Poschenrieder C. Interactions between aluminum and boron in tea (Camellia sinensis) plants. Acta Physiol Plant. 2015;37:54.

44. Nagayama T, Nakamura A, Yamaji N, Satoh S, Furukawa J, Iwai H. Changes in the distribution of pectin in root border cells under aluminum stress. Front Plant Sci. 2019;10:1216.

45. Li XW, Li YL, Qu M, Xiao HD, Feng YM, Liu JY, Wu LS, Yu M. Cell wall pectin and its methyl-esterification in transition zone determine Al resistance in cultivars of pea (Pisum sativum). Front Plant Sci. 2016;7:39.

46. Ma JF, Shen RF, Nagao S, Tanimoto E. Aluminum targets elongating cells by reducing cell wall extensibility in wheat roots. Plant Cell Physiol. 2004;45(5):583-9.

47. McCann MC, Chen L, Roberts K, Kemsley EK, Sene C, Carpita NC, Stacey NJ, Wilson RH. Infrared microspectroscopy: sampling heterogeneity in plant cell wall composition and architecture. Physiol Plant. 1997;100(3):729-38
48. Chen L, Carpita NC, Reiter WD, Wilson RH, Jeffries C, McCann MC. A rapid method to screen for cell-wall mutants using discriminant analysis of Fourier transform infrared spectra. Plant J Mol Biol. 1998;16(3):385-92.

49. Chatjigakis AK, Pappas C, Proxenia N, Kalantzi O, Rodis P, Polissiou M. FTIR spectroscopic determination of the degree of esterification of cell wall pectins from stored peaches and correlation to textural changes. Carbohydr Polym. 1998;37(4):395-408.

50. Barron C, Parker ML, Mills E, Rouau X, Wilson RH. FTIR imaging of wheat endosperm cell walls in situ reveals compositional and architectural heterogeneity related to grain hardness. Planta. 2005;220(5):667-77.

51. Hsu PH. Effect of initial pH, phosphate, and silicate on the determination of aluminum with aluminon. Soil Sci. 1963;96(4):230-8.

52. Zhong HL, Lauchli A. Changes of cell wall composition and polymer size in primary roots of cotton seedlings under high salinity. J Exp Bot. 1993:44(261):773-8.

53. Huang WL, Wu FL, Huang HY, Huang WT, Deng CL, Yang LT, Huang ZR, Chen LS. Excess copper-induced alterations of protein profiles and related physiological parameters in citrus leaves. Plants-Basel. 2020;9(3):291.

54. Livak KJ, Schmittgen TD. Analysis of relative gene expression data using real-time quantitative PCR and the $2^{-\triangle \triangle C T}$ method. Methods. 2001;25(4):402-8

55. Zheng SJ, Lin X, Yang J, Liu Q, Tang C. The kinetics of aluminum adsorption and desorption by root cell walls of an aluminum resistant wheat (Triticum aestivum L.) cultivar. Plant Soil. 2004;261(1):85-90.

\section{Publisher's Note}

Springer Nature remains neutral with regard to jurisdictional claims in published maps and institutional affiliations.
Ready to submit your research? Choose BMC and benefit from:

- fast, convenient online submission

- thorough peer review by experienced researchers in your field

- rapid publication on acceptance

- support for research data, including large and complex data types

- gold Open Access which fosters wider collaboration and increased citations

- maximum visibility for your research: over $100 \mathrm{M}$ website views per year

At BMC, research is always in progress.

Learn more biomedcentral.com/submissions 